\title{
Impaired ACTH and glucagon response to hypoglycaemia in an insulin-treated diabetic
}

\author{
A. E. OHWOVORIOLE* \\ M.B., F.M.C.P. \\ J. BEVAN
M.B., B.S.
}

I. M. NAIRN

F.I.M.L.S.

J. D. BAIRD

M.B., F.R.C.P.

Metabolic Unit, Western General Hospital, Edinburgh EH4

\begin{abstract}
Summary
A 32-year-old woman who had been diabetic for 24 years presented with frequent, oligosymptomatic episodes of hypoglycaemia. Investigations showed that she had attenuated adrenocortical and pancreatic A-cell response to hypoglycaemia. Her plasma ACTH response to hypoglycaemia was also impaired but there was normal adrenocortical response to the injection of synthetic ACTH. Plasma glucagon response to intravenous arginine was also normal.
\end{abstract}

It is concluded that the blunted plasma cortisol response to insulin-induced hypoglycaemia in some long-standing diabetics is due to a pituitary or higher dysfunction, rather than adrenocortical dysfunction.

\section{Introduction}

Counter-regulatory hormonal response to hypoglycaemia has been reported to be impaired in diabetics by several workers (Goldfien et al., 1961; Molnar et al., 1971; Campbell et al., 1979; Skyler, 1979). The absent or impaired plasma glucagon response to hypoglycaemia has been better documented in these subjects (Maher et al., 1977). The lack of an adequate response of the pancreatic A-cells has been attributed to the decreased sensitivity to glucose by these cells. The degree of impairment of response of plasma cortisol and growth hormone has been controversial. Some workers have found no significant relationship between counter-regulatory hormonal changes and glucose recovery from insulin-induced hypoglycaemia in diabetics (Gale, Kurtz and Tattersall, 1980). On the other hand Campbell et al. (1979) found significantly less hormo-

\footnotetext{
*Correspondence to: Dr A. E. Ohwovoriole, Department of Medicine, Lagos University Teaching Hospital, P. M. B. 12003 , Lagos, Nigeria.
}

nal response to hypoglycaemia in long-standing and unstable diabetics than in normal subjects. The majority of opinion appears to favour the view that there is impairment of hormonal response to hypoglycaemia in some long-standing diabetics. The level at which there is such impairment to glucose sensing has not been well defined in relation to the hypothalamo-pituitary-adrenal axis. We report a case in which there was evidence that the impaired response of plasma cortisol was due to a dysfunction at the pituitary or higher level.

\section{Case report}

A 32-year-old nurse who had been diabetic for over 24 years was admitted because of frequent oligosymptomatic episodes of hypoglycaemia. Episodes of hypoglycaemia occurred without warning. She was on a twice daily regime of soluble and lente insulin, at a mean daily dose of $1.0 \mathrm{u} . / \mathrm{kg}$ body weight.

On admission she weighed $56 \mathrm{~kg}$ and was $165 \mathrm{~cm}$ tall. Systemic examination was essentially normal except for the presence of an ejection systolic murmur which was shown to be due to a bicuspid aortic value.

Her blood count and serum biochemistry were normal as was the chest radiograph. Her autonomic nervous system function was kindly assessed by $\mathrm{Dr}$ D. J. Ewing of the Royal Infirmary, Edinburgh. Her supine and erect blood pressures were $125 / 75 \mathrm{mmHg}$ and $120 / 75 \mathrm{mmHg}$ respectively. The Valsalva ratio (ratio of the R-R interval after the manoeuvre to the shortest $R-R$ interval during the manoeuvre), the rise in diastolic blood pressure during a sustained hand grip and the heart rate response ( $R-R$ interval variation) to standing were all within normal limits. Her exocrine pancreatic function tests as assessed by 
a five-day faecal fat collection and tryptic activity after a test meal were normal. Thyroid function tests were also within normal limits.

Serial overnight urinary cortisol/creatinine ratios (UCCR) ranged from $9 \cdot 2$ to 18.4 (normal mean \pm s.d. $=8 \cdot 5 \pm 3.8$ ). The blood glucose levels observed during an overnight monitoring of blood variables are shown in Table 1.

TABLE 1. Biochemical findings during an overnight study of patient

\begin{tabular}{lccc}
\hline $\begin{array}{l}\text { Time } \\
\text { (Hr) }\end{array}$ & $\begin{array}{c}\text { Blood glucose } \\
\text { (mmol/litre) }\end{array}$ & $\begin{array}{c}\text { Plasma cortisol } \\
\text { (nmol/litre) }\end{array}$ & $\begin{array}{c}\text { Plasma growth } \\
\text { hormone (mu./litre) }\end{array}$ \\
\hline 2300 & 5.8 & 200 & $2 \cdot 6$ \\
0100 & 2.3 & 130 & 1.9 \\
0200 & 1.3 & 98 & $38 \cdot 5$ \\
0300 & $1 \cdot 1$ & 390 & $49 \cdot 6$ \\
0400 & 1.6 & 420 & $42 \cdot 8$ \\
0500 & 1.5 & 410 & $28 \cdot 0$ \\
0700 & 2.0 & 520 & $10 \cdot 4$ \\
\hline
\end{tabular}

Plasma glucagon was below assay sensitivity level ( $<5 \mathrm{pmol} /$ litre).

During the period of about $5 \mathrm{hr}$ when she was biochemically hypoglycaemic, she showed few signs of hypoglycaemia. Her maximum pulse rate during the night was 72 beats/minute and she had an apparently comfortable sleep.

In order to assess her hypothalamo-pituitaryadrenal axis in a more standard way, she had an insulin stress test done as well as the short tetracosactrin (Synacthen) test. The findings during the standard intravenous insulin stress test were similar to those of the night study and are shown in Table 2.

During the insulin stress test she quietly lapsed into hypoglycaemic pre-coma and she had to be resuscitated with intravenous glucose. Plasma glucagon, cortisol and ACTH responses were absent or blunted. Her UCCR on the day of the night study and after the insulin stress test were similarly attenuated at 18.4 and 18.9 respectively (normal mean \pm s.e. post insulin-stress test UCCR in our laboratory is $54 \pm 6$ ).

Following the short Synacthen test, there was a brisk and adequate response of plasma cortisol from a basal level of $270 \mathrm{nmol} /$ litre to a peak of 800 nmol/litre at $45 \mathrm{~min}$. She also responded normally to intravenous infusion of arginine; plasma glucagon levels rose from less than $5 \mathrm{pmol} / \mathrm{litre}$ at $0 \mathrm{~min}$ to 20 $\mathrm{pmol} /$ litre at $45 \mathrm{~min}$. During the periods when she was hyperglycaemic (blood glucose $>8.0 \mathrm{mmol} /$ litre), there was no measurable $\mathrm{C}$-peptide in her plasma on two occasions.

When her insulin was reduced from $1 \cdot 0 \mathrm{u} . / \mathrm{kg} / 24$ $\mathrm{hr}$ to $0.57 \mathrm{u} . / \mathrm{kg} / 24 \mathrm{hr}$, she improved symptomatically. There was also a marked fall in her mean UCCR from $13.7 \pm 1.3$ to $6.7 \pm 0.81$, which was well within the normal range for the laboratory.

\section{Discussion}

The clinical and biochemical findings in this patient are very similar to the cases described by Gale and Tattersall (1979). Of their 22 insulin-treated diabetics with nocturnal hypoglycaemia, only one was awoken by hypoglycaemic symptoms. The features of over-insulinized diabetics are well reviewed by Rosenbloom and Giordano (1977), Skyler (1979) and Gale and Tattersall (1979).

The failure of glucose recovery during hypoglycaemia in some diabetics has been attributed to the diminished response of the anti-insulin hormones (growth hormone, glucagon, cortisol and the catecholamines). The diabetic subjects with such impaired counter-regulatory mechanisms tend to be more labile. However, Gale et al. (1980) found no significant difference in the response of plasma cortisol and growth hormone in diabetics with post-hypoglycaemic rebound and those without rebound hyperglycaemia.

The role of chronic hypoglycaemia in the causation of impaired counter-regulatory hormonal response to insulin-induced hypoglycaemia is not clear. However, the phenomenon of impaired hormonal response to hypoglycaemia appears common among insulin-treated diabetics (Skyler, 1979; Campbell et al., 1979).

TABLE 2. Biochemical findings during insulin tolerance test in the same patient

\begin{tabular}{ccccc}
\hline $\begin{array}{l}\text { Time } \\
\text { (mins) }\end{array}$ & $\begin{array}{c}\text { Blood glucose } \\
\text { (mmol/litre) }\end{array}$ & $\begin{array}{c}\text { Plasma cortisol } \\
\text { (nmol/litre) }\end{array}$ & $\begin{array}{c}\text { Plasma } \\
\text { ACTH } \\
\text { (pmol/litre) }\end{array}$ & $\begin{array}{c}\text { Plasma } \\
\text { growth } \\
\text { hormone } \\
\text { (mu./litre) }\end{array}$ \\
\hline-15 & 0.49 & 240 & 5.8 & 0.37 \\
0 & 4.1 & 220 & 5.5 & 0.37 \\
30 & 2.6 & 480 & $5 \cdot 7$ & 32.2 \\
60 & 0.8 & 400 & 5.5 & 31.2 \\
90 & $* * 5$ & 235 & 5.5 & 22.3 \\
120 & 3.2 & 193 & 19.8 & 6.7 \\
\hline
\end{tabular}

Plasma glucagon was below assay sensitivity level ( $<5 \mathrm{pmol} /$ litre).

**After $50 \mathrm{ml}$ of $50 \%$ dextrose given at $60 \mathrm{~min}$. 
The impaired response of the pancreatic A-cells to hypoglycaemia but with normal response to other stimulants like arginine in insulin-treated diabetics is well known (Campbell et al., 1979). The explanation is unclear but Ohneda et al. (1969) have suggested that arginine has a powerful stimulatory action on the A-cells and may be too strong a stimulant to detect partial glucagon deficiency. A central (hypothalamo-pituitary) cause is also possible as it is known that insufficiency of either growth hormone or the adrenocortical steroids leads to a blunting of the endocrine pancreatic response to changing blood glucose concentrations (Van Lan et al., 1974).

Using plasma cortisol changes in response to insulin-induced hypoglycaemia, the adrenocortical response could be taken as borderline or equivocal in this patient. However, the blunted adrenocortical response to hypoglycaemia was more clearly shown by the relatively low urinary cortisol-creatinine ratio after the insulin stress test. This measurement may be more discriminatory between normal and subnormal adrenocortical response to insulin-induced hypoglycaemia (Ohwovoriole et al., 1982).

Though several workers have commented on the blunted plasma cortisol response to hypoglycaemia in long-standing diabetics, information on the ACTH response in these patients is scanty. Campbell et al. (1979) suggested that this acquired defect in counterregulatory control is probably of central origin. Boden et al. (1981) have recently described a case similar to the one in this report and they also suggest that the dysfunction is at the hypothalamic or low brainstem level. The finding of a normal adrenocortical response to synthetic ACTH in the patient described by Boden et al. (1981) and in this patient reinforces this suggestion.

\section{Acknowledgments}

We are grateful to Mrs C. A. Macfarlane for technical assistance, to $\mathrm{Dr}$ J. E. Seth for the determination of plasma hormones and to
Professor J. A. Strong for the provision of facilities. We are indebted to Dr D. J. Ewing of the Royal Infirmary, Edinburgh for kindly assessing the patient's autonomic nervous system function. We thank Mr M. O. Olayinka for his secretarial help.

\section{References}

Boden, G., Reichard, G.A., Hoedtke, R.D., Rezvani, I. \& OWen, O.E. (1981) Severe insulin-induced hypoglycaemia associated with deficiencies in the release of counterregulatory hormones. New England Journal of Medicine, 305, 1200.

Campbell, L.V., Kraegen, E.W., Neller, H. \& Lazarous, L. (1979) Hormonal responses to insulin infusion in diabetes mellitus. Diabetologia, 16, 359.

Gale, E.A.M., KurTZ, A.B. \& TAtTersall, R.B. (1980) In search of the Somogyi effect. Lancet, ii, 279.

GALE, E.A.M. \& TATTERSALL, R.B. (1979) Unrecognised nocturnal hypoglycaemia in insulin-treated diabetics. Lancet, i, 1049.

Goldfien, A., Moore, R., Zileli, S., Harens, L.L., Boling, L. \& ThORN, G.W. (1961) Plasma epinephrine and norepinephrine levels during insulin-induced hypoglycaemia in man. Journal of Clinical Endocrinology and Metabolism, 21, 281.

MAHER, T.D., TANenberg, R.J., GReEnberG, B.Z., HoffmAn, J.E., DUE, R.P. \& GOETZ, F.C. (1977) Lack of glucagon response to hypoglycaemia in diabetic autonomic neuropathy. Diabetes, 26 , 196.

Molnar, G.D., Fatourechi, V., Ackerman, E., Taylor, W.F., Rosevear, J.W., Galewood, L.C., Service, F.J. \& Moxness, K.E. (1971) Growth hormone and glucose interrelationships in diabetes: Studies of inadvertent hypoglycaemic episodes during continuous glucose analysis. Journal of Clinical Endocrinology and Metabolism, 32, 426.

Ohneda, A., Agular-Parada, E., Elsentraut, A.M. \& Unger, R.H. (1969) Control of glucagon secretion by glucose. Diabetes, 18, 1.

Ohwovoriole, A.E., NaIRn, I.M., Baird, J.D. \& STRONG, J. (1982) Urinary cortisol-creatinine ratio: use in the evaluation of adreno-e cortical response to insulin tolerance test. Nigerian Quarterly? Journal of Medicine, (in press).

Rosenbloom, A.L. \& Giordano, B.P. (1977) Chronic overtreatment with insulin in children and adolescents. American Journal of Disease of Children, 131, 881.

SKYLER, J.S. (1979) Counter-regulatory hormones, rebound hyperglycaemia, and diabetic control. Diabetes Care, 2, 526.

Van Lan, V., Yamaguchi. N., Garcia, M.J., Ramay, E.R. \& PENHOS, J.C. (1974) Effect of hypophysectomy and adrenalectomy on glucagon and insulin concentration. Endocrinology, 94, 671 . 